\title{
PENGARUH BRAND IMAGE TERHADAP KEPUTUSAN PEMBELIAN PRODUK ADIDAS DI PARIS VAN JAVA BANDUNG
}

\author{
Dyah Ayu Lestari ${ }^{1}$, Ida Nurnida $^{2}$ \\ ${ }^{12}$ Fakultas Komunikasi dan Bisnis Universitas Telkom \\ 1heagea16@gmail.com
}

\begin{abstract}
Abstrak
Industri produk olahraga saat ini sangat kompetitif dalam menentukan bentuk, warna dalam merek produknya. Brand image merupakan hal yang paling penting jika produk menjadi lebih kompleks dan ramai dipasaran. Penelitian ini bertujuan untuk mengetahui pengaruh brand image terhadap keputusan pembelian produk Adidas di Paris Van Java Bandung. Penelitian ini menggunakan metode kuantitatif dengan jenis penelitian deskriptif-kausalitas. Pengambilan sampel dilakukan dengan metode non-probability sampling dengan insidental sampling menggunakan sebanyak 100 responden. Teknik analisis data yang digunakan yaitu analisis regresi linear berganda. Berdasarkan hasil uji hipotesis secara parsial menunjukkan bahwa keunggulan dan keunikan merek berpengaruh terhadap keputusan pembelian. Hasil koefisiensi determinasi brand image berpengaruh terhadap keputusan pembelian sebear $64,3 \%$ dan sisanya sebesar 35,7\% dipengaruhi oleh faktor lain yang tidak diteliti dalam penelitian ini.
\end{abstract}

Kata kunci: Brand Image, Keunggulan merek, Kekuatan Merek, Keunikan Merek, Keputusan Pembelian

\section{THE IMPACT OF BRAND IMAGE ON PRODUCT PURCHASING DECISIONS ADIDAS IN PARIS VAN JAVA BANDUNG}

\author{
Dyah Ayu Lestari ${ }^{1}$, Ida Nurnida ${ }^{2}$ \\ ${ }^{12}$ Fakultas Komunikasi dan Bisnis Universitas Telkom \\ 1heagea16@gmail.com
}

\begin{abstract}
Sports product industry is currently very competitive in determining the shape, the colors in the brand products. Brand image is the most important thing if products become more complex and crowded market. This study aims to determine the effect of brand image on product purchasing decisions Adidas in Paris Van Java Bandung. This study uses quantitative methods with descriptive research-causality. Sampling was done by non-probability sampling method by using incidental sampling of 100 respondents. Data analysis technique used is multiple linear regression analysis. Based on the partial results of hypothesis testing showed that the excellence and uniqueness of brand influence on purchase decisions. Results of determination coefficient brand image influence on purchase decisions implanted at $64.3 \%$ and the remaining $35.7 \%$ is influenced by other factors not examined in this study.
\end{abstract}

Keywords: Brand Image, Brand Advantage, Brand Strength, Brand Uniqueness, Purchasing Decisions 


\section{PENDAHULUAN}

Pada zaman modern seperti sekarang, salah satu industri yang mengalami peningkatan pesat adalah industri dibidang perlengkapan olahraga, yang disebabkan karena tumbuhnya kesadaran masyarakat akan pentingnya hidup sehat. Kenyataan ini menjadi sebuah peluang bagi produsen pakaian, sepatu dan perlengkapan olahraga, untuk berlomba-lomba dalam menarik minat konsumen terhadap produknya.

Industri produk olahraga saat ini sangat kompetitif dalam menetukan bentuk, warna, dan merek pada produknya. Merek pakaian, sepatu dan peralatan olahraga yang beredar di pasar industri olahraga Indonesia sangat beragam seperti Adidas, Nike, Puma, Yonex, Reebok, Joma, dan Lotto. Merek tersebut banyak diminati oleh masyarakat Indonesia. Setiap merek menetapkan harga yang cukup bersaing sesuai jenis dan segmen pasarnya.

Pada sisi lain, perusahaan yang baik juga harus selalu berusaha untuk memahami keputusan pembelian pelanggan dengan baik, dengan kata lain produsen dapat memberikan kemudahan bagi konsumen untuk menentukan pilihan sesuai dengan selera dan kemampuan daya beli mereka.

Dari hasil survey peneliti dapat dilihat bahwa sebenarnya citra merek dari produk Adidas belum sepenuhnya baik, terutama pada sub variabel kekuatan merek, hanya $30 \%$ responden yang dapat mengetahui informasi yang diberikan oleh Adidas, sedangkan $70 \%$ responden tidk mengetahui infoormasi apa saja yang diberikan Adidas. Hal ini disebabkan banyaknya konsumen yang tidak secara langsung dapat berkomunikasi dengan produsen dan kurangnya media untuk menyampaikan informasi. Sehingga Adidas membutuhkan inovasi-inovasi baru untuk dapat dengan mudah menyampaikan informasi tentag Adidas agar dengan mudah sampai ke konsumen.

Berikut ini tabel yang menunjukkan bahwa Adidas menjadi market leader dengan merek produk olahraga yang berada di Indonesia, sebagai berikut :

\section{Tabel 1. Top Brand Index Produk Pakaian Olahraga Indonesia} Presentasi Penjualan per

\begin{tabular}{lllll} 
No. & Brand & \multicolumn{3}{c}{ Tahun } \\
\cline { 3 - 5 } & & $\mathbf{2 0 1 4}$ & $\mathbf{2 0 1 5}$ & $\mathbf{2 0 1 6}$ \\
\hline 1. & Adidas & $58.2 \%$ & $57.8 \%$ & $45.3 \%$ \\
2. & Nike & $19.3 \%$ & $23.1 \%$ & $37.5 \%$ \\
3. & Puma & $6.0 \%$ & $4.6 \%$ & $3.7 \%$ \\
5. & Reebok & $2.6 \%$ & $2.9 \%$ & $3.9 \%$
\end{tabular}

(sumber: www.topbrand-award.com)

Berdasarkan tabel di atas dapat dilihat bahwa terjadi penurunan penjualan Adidas secara signifikan yaitu tahun 2014 Adidas mampu menjual sekitar 58,2 \%, tetapi tahun 2015 mengalami penurunan presentasi sebesar $0.4 \%$ menjadi 57,8\% dan pada tahun 2016 menurun lagi 
menjadi 45,3\%. Hal ini disebabkan karena terjadinya persaingan antara Adidas dan Nike yang selalu bersaing dalam sponsor pemain, sponsor klub, dan desain pada produk sepatu.

Persaingan tersebut menyebabkan konsumen menjadi semakin selektif dalam memilih merek peralatan olahraga yang benar-benar sesuai dengan keinginan dan kebutuhannya. Konsumen akan semakin ingin mengetahui penetapan brand image yang dilakukan oleh Adidas, sehingga perusahaan dapat mengetahui bagaimana cara pembeli melakukan keputusan pembelian produk Adidas dan pada akhirnya mengetahui pengaruh brand image terhadap keputusan pembelian produk Adidas

Sofjan (2015: 204) menyatakan bahwa merek adalah nama, istilah, tanda atau lambang dan kombinasi dari dua atau lebih unsur tersebut, yang dimaksudkan untuk mengidentifikasi (barang atau jasa) dari seorang penjual atau kelompok penjual dan yang membedakannya dari produk saingan.

Merek merupakan bagian dari analisis sebuah produk dimana merek dapat memberikan identifikasi terhadap suatu produk, sehingga konsumen mengenal merek yang berbeda dari produk lainnya (Sofjan, 2015: 206).

Hawkins (dalam Ismail, 2013: 62) menyatakan bahwa citra merek cenderung kepada skematik memori tentang merek yang berisi interprestasi pasar target terhadap atribut produk, manfaat, situasi penggunaan, pengguna dan karakteristik perusahaan.

Menurut Ferrinadewi (2009: 165), faktor-faktor pendukung terbentuknya citra merek dapat dijelaskan sebagai berikut :

\section{a. Keunggulan Merek (Favorability of Brand)}

Keunggulan merek adalah asosiasi merek yang meyatakan bahwa konsumen percaya akan manfaat dan atribut yang diberikan oleh merek tersebut akan dapat memenuhi atau memuaskan keinginan dan kebutuhan konsumen sehingga konsumen memberi sikap positif terhadap merek tersebut.

\section{b. Kekuatan Merek (Strenght of Brand)}

Keunggulan merek itu tegantung pada bagaimana informasi masuk kedalam ingatan konsumen dan bagaimana proses bertahan sebagai bagian dri citra merek. Dalam membuat kekuatan merek dapat menggunakan bauran promosi komunikasi pemasaran (promotion mix), seperti :

1) Periklanan

2) Promosi penjualan 
3) Hubungan masyarakat dan publisitas

4) Penjualan secara pribadi

\section{c. Keunikan Merek (Uniqueness of} Brand)

Keunikan asosiasi merek merupakan asosiasi yang menjadikan sebuah merek memiliki keunikan dan menarik sehingga produk tersebut memilki ciri khas dan berbeda dari pesaing. Keunikan sebuah merek akan menarik perhatian dan memberi kesan untuk para konsumennya. Sebuah brand yang memiliki ciri khas yang kuat terhadap produknya harus dapat melahirkan keinginan konsumen untuk mengetahui lebih jauh tentang keunikan apa yang dimiliki oleh produk tersebut

Keputusan pembelian menurut Kotler (2009: 188), adalah suatu tindakan konsumen untuk membentuk referensi diantara merek-merek dalam kelompok pilihan dan membeli produk yang paling disukai. Menurut Thamrin (2012: 128) perusahaan yang bijak akan meneliti proses keputusan pembelian yang melibatkan kategori produk perusahaan, dengan demikian perusahaan dapat mengetahui bagaimana konsumen membuat pilihan terhadap sebuah produk.

Dalam melakukan maksud pembelian, konsumen dapat membentuk lima subkeputusan : pemilihan produk, pemilihan merek, pemilihan saluran pembelian, waktu pembelian, dan cara pembayaran (Kotler \& Keller, 2012:193).

\section{METODE}

Jenis penelitian ini menggunakan metode analisis deskriptif dan kausalitas dengan pendekatan kuantitatif. Ppenelitian kausalitas digunakan untuk meneliti hubungan sebab akibat antara dua variabel atau lebih (Silalahi, 2009:33). Menurut Sugiyono (2013:35) penelitian kuantitatif merupakan metode penelitian berlandaskan pada filsafat, digunakan untuk meneliti populasi atau sampel tertentu, pengumpulan data menggunakan instrumen penelitian, analisis data bersifat statistik dengan tujuan untuk menguji hipotesis yang telah ditetapkan.

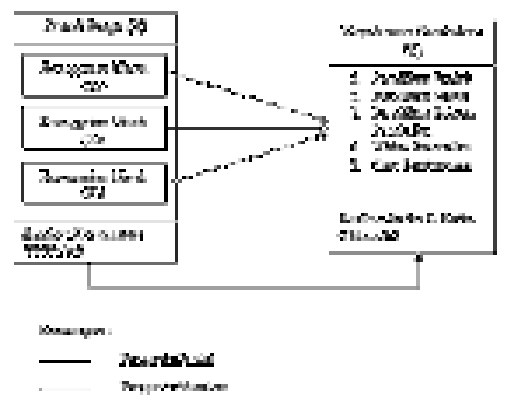

\section{Gambar 1. Kerangka Pemikiran Peneliti}

\section{Variabel Penelitian}

Terdapat dua variabel penelitian yang digunakan dalam penelitian ini, yaitu:

1. Variabel bebas yaitu brand image $(\mathrm{X})$, dengan sub-variabel antara lan keunggulan merek $\left(\mathrm{X}_{1}\right)$, kekuatan 
merek $\left(\mathrm{X}_{2}\right)$, dan keunikan merek $\left(\mathrm{X}_{3}\right)$.

2. Variabel terikat yaitu keputusan pembelian (Y) dengan dimensi pemilihan produk, pemilihan merek, pemilihan saluran pembelian, waktu pembelian dan cara pembayaran.

\section{Metode Pengumpulan Data}

Ferdinand (2011: 215), populasi merupakan gabungan dari seluruh elemen yang terbentuk peristiwa, hal atau orang yang memiliki karakteristtik yang serupa yang menjadi pusat perhatian seorang peneliti karena itu dipandang sebagai sebuah semesta penelitian. Dalam penelitian ini peneliti menggunakan responden ialah konsumen yang pernah membeli produk Adidas di Paris Van Java Bandung.

Teknik sampling yang digunakan daam penelitian ini adalah non-probability sampling dengan insidental sampling yaitu teknik pengambilan sampel yang tidak memberi peluang yang sama bagi setiap unsur atau anggota populasi yang dipilih menjadi sampel (Sugiyono, 2013:154).

Pada penelitian ini, mengingat jumlah populasi tidak diketahui maka dalam menentukan jumlah sampel menggunakan rumus Bernoulli (Siregar, 2013:37). Berdasarkan hasil hitung sampel, diperoleh angka 96 untuk jumlah sampel minimum, tetapi penulis membulatkannya menjadi 100 responden untuk mengantisipasi terjadinya kesalahan pengisian kuesioner.

\section{Teknik Pengumpulan Data}

Data primer adalah data yang langsung diperoleh dari sumber data kepada pengumpul data (Sugiyono, 2014: 137). Dalam hal ini peneliti menggunakan kuesioner dan sumber data responden sebagai data primer. Menurut (Sugiyono, 2013: 230), kuesioner sendiri adalah teknik pengumpulan data yang dilakukan dengan cara memberi seperangkat pertanyaan atau pernyataan tertulis kepada responden untuk dijawab. Responden dalam penelitian ini adalah konsumen yang pernah membeli produk Adidas di Paris Van Java Bandung.

\section{Uji Validitas dan Reliabilitas}

Sugiyono (2012), menyatakan bahwa validitas merupakan derajat ketepatan antara data yang sesungguhnya terjadi pada objek penelitian dengan data yang dapat dilaporkan oleh peneliti. Untuk menguji validitas dari setiap butir pernyataan yang ada dalam kuesioner sebelum kuesioner disebarkan kepada responden yang sebenarnya, dilakukan uji coba kuesioner kepada 30 orang responden untuk mengetahui baik atau 
tidaknya kuesioner. Nilai $\mathrm{r}$ tabel untuk $\mathrm{N}$ $=30$ dengan taraf signifikasi 5\% $(\alpha=$ 0,05) diperoleh angka 0,361 (Sugiyono 2012: 333).

Uji reliabilitas sebenarnya adalah alat untuk mengukur suatu kuesioner yang merupakan indikator dari variabel atau konstruk, menurut Ghozali (2011: 47). Kuesioner dapat dikatakan reliabel apabila jawaban dari setiap responden konsisten atau stabil dari waktu ke waktu. Pengolahan data tersebut dapat dilakukan dengan menggunakan SPSS.

\section{Analisis Regresi Linier Berganda}

Analisis regresi linier berganda digunakan untuk pengukuran pengaruh antar variabel yang melibatkan lebih dari satu variabel bebas $(\mathrm{X} 1, \mathrm{X} 2, \mathrm{X} 3, \ldots, \mathrm{Xn})$ (Sunyoto, 2012: 13).

\section{HASIL DAN PEMBAHASAN}

\section{Analisis Deskriptif}

Berdasarkan penelitian dari analisis deskriptif, produk Adidas memberikan kategori baik dalam variabel keunggulan merek sebesar 81,4\%. Hal ini menunjukkan bahwa produk Adidas memang memberikkan kualitas terbaiknnya terhadap konsumen. Variabel kekuatan merek mendapatkan hasil presentase sebesar $82,8 \%$ dalam kategori baik, produk Adidas memberikan pengaruh yang tinggi terhadap penggunanya sehingga konsumen yang menggunakan produk tersebut merasa lebih percaya diri dan puas terhadap produk itu sendiri. Dan variabel yang mendapatkan presentase tertinggi adalah keunikan merek sebesar 83,75\%, hal tersebut menunjukkan bahwa Adidas dapat dengan mudah diingat dan melekat dibenak para konsumen.

Keputusan pembelian secara keseluruhan mendapatkan presentase sebesar $82,4 \%$ berada dikategori baik. Hal tersebut dipengaruhi oleh beberapa faktor yang mendorong konsumen dalam melakukan keputusan pembelian.

\section{Analisis Regresi Linear Berganda}

$$
\begin{gathered}
Y=3,244+0,275 X_{1}+0,141 X_{2}+ \\
0,483 X_{3}
\end{gathered}
$$

Berdasarkan persamaan di atas dapat diuraikan sebagai berikut :

a. Konstanta (a) $=3,244$. Menunjukkan nilai konstan, yaitu jika variabel keunggulan $\left(\mathrm{X}_{1}\right)$, kekuatan $\left(\mathrm{X}_{2}\right)$ dan keunikan $\left(\mathrm{X}_{3}\right)=$ 0 , maka keputusan pembelian produk Adidas di Paris Van Java Bandung tetap sebesar 3,244.

b. Koefisien $X_{1} \quad\left(b_{1}\right)=0,275$. Menunjukkan bahwa variabel keunggulan merek berpengaruh secara positif terhadap keputusan pembelian produk Adidas di Paris Van Java Bandung, dengan kata 
lain apabila variabel keunggulan merek ditingkatkan menjadi satusatuan, maka keputusan pembelian akan bertambah 0,275.

c. Koefisien $\mathrm{X}_{2} \quad\left(\mathrm{~b}_{2}\right)=0,141$. Menunjukkan bahwa variabel kekuatan merek berpengaruh secara positif terhadap keputusan pembelian produk Adidas di Paris Van Java Bandung, dengan kata lain apabila variabel kekuatan merek ditingkatkan menjadi satusatuan, maka keputusan pembelian akan bertambah 0,141 .

d. Koefisien $\mathrm{X}_{3} \quad\left(\mathrm{~b}_{3}\right)=0,483$. Menunjukkan bahwa variabel keunikan merek berpengaruh secara positif terhadap keputusan pembelian produk Adidas di Paris Van Java Bandung, dengan kata lain apabila variabel keunikan merek ditingkatkan menjadi satusatuan, maka keputusan pembelian akan bertambah 0,483 .

\section{Pengujian Hipotesis}

\section{Uji T}

Berdasarkan hasil pengolahan data menggukan SPSS dapat dilihat bahwa :

a. Nilai $t$ test variabel keunggulan merek lebih besar dari $t$ tabel. Karena nilai $t$ test variabel keunggulan merek sebesar 3,225, sedangkan $\mathrm{t}$ tabel sebesar 1,985 dan tingkat signifikansi variabel keunggulan merek lebih kecil dari 0,05 yaitu sebesar 0,002 maka H0 ditolak. Disimpulkan bahwa secara parsial terdapat pengaruh signifikan dari keunggulan merek (X1) terhadap keputusan pembelian.

b. Nilai $t$ test variabel kekuatan merek lebih kecil dari t tabel. Karena nilai $\mathrm{t}$ test variabel keunggulan merek sebesar 1,563, sedangkan $\mathrm{t}$ tabel sebesar 1,985 dan tingkat signifikansi variabel keunggulan merek lebih besae dari 0,05 yaitu sebesar 0,121 maka H0 diterima. Disimpulkan bahwa secara parsial tidak terdapat pengaruh signifikan dari kekuatan merek (X2) terhadap keputusan pembelian.

c. Nilai t test variabel keunikan merek lebih besar dari t tabel. Karena nilai t test variabel keunggulan merek sebesar 5,322, sedangkan $\mathrm{t}$ tabel sebesar 1,985 dan tingkat signifikansi variabel keunggulan merek lebih kecil dari 0,05 yaitu sebesar 0,000 maka H0 ditolak. Disimpulkan bahwa secara parsial terdapat pengaruh signifikan dari keunikan merek (X3) terhadap keputusan pembelian.

Uji F

Hasil pengolahan data SPSS menunjukkan bahwa $F$ test sebesar 
57,790 dengan tingkat signifikansi 0,000 .

Hal tersebut menunjukkan bahwa $\mathrm{F}$ test lebih besar dari pada $\mathrm{F}$ tabel dengan tingkat signifikasi $0,000<0,05$ maka $\mathrm{H} 0$ ditolak dan Ha diterima. Dengan demikian dapat disimpulkan bahwa brand image yang terdiri dari keunggulan, kekuatan, keunikan merek berpengaruh secara signifikan terhadap keputusan pembelian.

\section{Koefisiensi Determinasi}

Hasil pengolahan data SPSS menunjukkan bahwa nilai $\mathrm{R}$ sebesar 0,802 dan nilai $\mathrm{R}$ square $\left(\mathrm{R}^{2}\right)$ adalah 0,644 . Angka tersebut digunakan untuk melihat seberapa besar pengaruh brand image yang terdiri dari keunggulan, kekuatan dan keunikan merek terhadap keputusan pembelian secara simultan.

Hal tersebut menunjukkan bahwa pengaruh brand image yang terdiri dari keunggulan, kekuatan dan keunikan merek terhadap keputusan pembelian sebesar $64,3 \%$ sedangkan $35,7 \%$ sisanya dipengaruhi oleh faktor lain seperti bauran pemasaran yang tidak diteliti dalam penelitian ini.

\section{KESIMPULAN}

Dari hasil analisis dan pengolahan data dapat disimpulkan sebagai berikut:

1. Variabel keunggulan dan keunikan merek secara parsial berpengaruh signifikan terhadap keputusan pembelian produk Adidas di Paris Van Java Bandung, sedangkan variabel kekuatan merek secara pasial tidak berpengaruh signifikan terhadap keputusan pembelian produk Adidas di Paris Van Java Bandung. Besarnya pengaruh yang dimiliki oleh setiap sub variabel ialah keunikan merek memiliki persentase terbesar terhadap keputusan pembelian sebesar $36,6 \%$, hal ini menunjukkan bahwa faktor yang dapat mempengaruhi keputusan pembelian merupakan keunikan dari Adidas meliputi ciri khas produk, berkerjasama dengan orang-orang yang memiliki pengaruh besar di masyarakat dan lainnya. Pengaruh keunggulan merek hanya memberikan pengaruh sebesar $18,6 \%$, hal tersebut dipengaruhi oleh bentuk dan jenis produk, harga yang sesuai kualitas, bahan-bahan yang bain dan manfaat dari produk itu sendiri. Sedangkan pengaruh variabel kekuatan merek mendapatkan presetase terkecil sekitar 9,1\% terhadap keputusan pembelian produk Adidas di Paris Van Java Bandung, hal tersebut membuktikan bahwa keunggulan dari sebuah merek bukan menjadi faktor utama terhadap keputusan pembelian. 
2. Variabel keunggulan, kekuatan dan keunikan merek secara simultan berpengaruh signifikan terhadap keputusan pembelian produk Adidas di Paris Van Java Bandung. Besarnya pengaruh brand image (keunggulan, kekuatan dan keunikan merek) terhadap keputusan pembelian yaitu sebesar $64,3 \%$, sedangkan $35,7 \%$ dipengaruhi oleh faktor lain seperti bauran pemasaran yang tidak diteliti dalam penelitian ini.

\section{DAFTAR PUSTAKA}

Basu, Swastha. (2008). Manajemen Pemasaran Modern, Edisi Kedua. Yogyakarta: Liberty Offset.

Daryanto. (2008). Manajemen Pemasaran. Bandung: Sarana Tutorial Nurani Sejahtera.

Ferdinand, Agusty. (2011). Metode Penelitian Manajemen.

Ferrinadewi, Erna. (2008). Merek Dan Psikologi Konsumen, Implikasi Pada Strategi Pemasaran. Yogyakarta: Graha Ilmu.

Kotler dan Keller. (2009). Manajemen Pemasaran.Edisi 12 Jilid 1. Jakarta: Indeks.

Kotler dan Keller. (2009). Manajemen Pemasaran, Edisi 12 Jilid 2. Jakarta: Indeks.

Kotler dan Keller. (2012). Manajemen Pemasaran, Edisi 12 Jilid 2. Jakarta: Indeks.
Silalahi, Ulber. (2009). Metode Penelitian Sosial. Bandung: PT. Refika Aditama.

Sugiyono. (2008). Metode Penelitian Bisnis. Bandung: Alfabeta.

Sugiyono. (2013). Metode Oenelitian Kombinasi. Bandung: Alfabeta.

Sunyoto, Danang. (2011). Metodologi Penelitian Ekonomi. Yogyakarta: CAPS.

Syofian, Siregar. (2013). Metode Penelitian Kuantitatif. Jakarta: Kencana Prenada Media Group.

Thamrin dan Francis. (2012). Manajemen Pemasaran, Edisi 1, Cetakan ke5. Yogyakarta: Rajawali Pers.

Tjiptono, Fandy. (2008). Stratejik Pemasaran. Yogyakarta: ANDI.

Uma Sekaran. (2007). Research Methods For Business. Jakarta: Salemba Empat. 